JOAL. (JOURNAL OF APPIIEI) LINGUIS'IICS ANI) II'TERA'TURE)

Vol. 6 No. 2, 2021

ISSN (print): 2502-7816; ISSN (online): 2503-524X

Check for
updates Available online at https:/ / ejournal.unib.ac.id/index.php/joall/index doi: https:/ / doi.org/10.33369/joall.v6i2.13879

\title{
PHONOLOGICAL SYSTEM OF BANGKA MALAY LANGUAGE, TOBOALI DIALECT, IN SOUTH BANGKA REGENCY
}

\author{
${ }^{1}$ Herland Franley Manalu (D), 2 Bob Morison Sigalingging (iD, \\ ${ }^{3}$ Dini Wulansari \\ 1,2,3 Universitas Bangka Belitung, Indonesia
}

Corresponding email: herland.franley@gmail.com

\begin{abstract}
The factors that led to the extinction of a regional language dialect are the absence of inputting the vocabulary into a dictionary, recording the phonological system to academic articles, and the absence of language enthusiasts or linguists who want to maintain the existence of a dialect in a community. Therefore, this study aims to analyze the phonological system in the Toboali dialect as the variant of the Malay language in the South Bangka Regency. The research is triggered by the decreasing use of regional languages in society and it purports to identify and describe the phonological system of the Toboali dialect. To do that, this study uses a qualitative method in which the researchers firstly collected data, then analyzed and classified the data, and finally drew a conclusion. The Swadesh list which consists of 250 vocabularies was utilized during the interview. The researchers obtained the Toboali dialect words by gesturing or pointing to objects and images so the informants were able to pronounce the words and then the phonetic transcription could be written. Thus, the data obtained are accurate because the language obtained was not delivered in Indonesian but is purely pronounced in the Toboali dialect. The results of this study indicate that there are 7 vowels: [ə], [e], [o], [i], [o], [v], [a] and 19 consonants are found in the Toboali dialect: [b], [c], [d], [f], [g], [h], [j], [k], [1], [m], [n], [p], [r], [s], [t], $[\mathrm{w}],[\mathrm{y}],[\mathrm{z}]$, and $[\mathrm{y}]$.
\end{abstract}

Keywords: phonological system, Bangka Malay language, Toboali dialect.

\section{INTRODUCTION}

Since the last decade, linguists' interest in phonology as one of the linguistic branches of study has been increasing because of the need to preserve local languages. Linguists have to improve their ability to analyze the phonetic and phonological features of a language being studied to conduct research and preserve the local language. To realize the local language preservation, this 
study seeks out to analyze the phonological system in the Toboali dialect which is used in the Southern part of Bangka Island, Indonesia.

Gussenhoven (2004) explains that phonology deals with sounds produced in certain languages that are applied in the form of certain symphonies which are the structure of sounds in a language. Each language has a different phonological pattern from one another. For example, the word car is pronounced / ka:r/ in American English, but there is a final consonant deletion in British English / ka:/. Based on the phonological pattern example, this study focuses on the different phonological patterns contained in the Toboali dialect spoken in the different parts of the south Bangka areas.

This research was conducted due to the decreasing use of local languages in the community. Most people forget that language shows the identity of a nation. Kridalaksana (2008) states that language represents a nation, without a language the nation loses its identity. Scientific work shows the scientific community; without scientific work, the scientific community has no identity. Cultural identity is related to a language and to save the identity of a culture, the people must endeavor to preserve their language (Ulfa et al., 2018). Therefore, it is with the linguistic scientific community, including its citizens. Without scientific work citizens of the linguistic community do not have an identity. As a citizen of the linguistic scientific community at the University of Bangka Belitung, the researcher sought to make scientific work through this study in analyzing the Toboali dialect phonological system, which is also expected to arouse the enthusiasm of other linguistic scientific citizens in preserving their regional languages.

This study, focusing on the Toboali dialect phonology system, was conducted based on Indonesian language phonetic transcription rules to meet the established quality criteria. The transcription of the human language sound is conducted in two branches of study: phonetics, and phonology. The former aims to study how the sounds of language are produced by humans, while the latter focuses on studying the sound systems and patterns that exist in a particular language (Cohn et al., 1992).

In phonology, a set of sounds that are considered equal and can distinguish meaning in a language system is called a phoneme (Diani \& Azwandi, 2021). This small set of speech sounds is abstracted by the speakers of a particular language. Phonemes are usually denoted by letters between slashes and they consist of allophones which are variations of the real form of the phonemes. While the allophone itself is derived from the phones, which are sounds that are grouped as members of the sounds (allophone) of the phoneme (Carr, 2013). In addition, phonemes can also be defined as the smallest language unit in the form of sound or aspects of language that distinguish the form and meaning of language. Then, if there are two 
phonetically similar sounds of a language that do not distinguish words, the two sounds are referred to as allophones of the same phoneme (Hasan, 2007).

Phonemes form a language system that can be obtained by searching for minimal pairs. Minimum pairs are two words that are almost the same because they only have one different segment. By conducting the minimal pairing test, we will get sound units that differentiate meaning or phonemes (Carr, 2013). Language sounds can be divided into two types: vowels and consonants. The distinction is based on the presence or absence of obstacles to air currents in the sound channel. Vowels are the sounds where the airflow is free of obstacles and the quality is determined by three factors: the high and low position of the tongue, the tongue is raised and the shape of the lips during the pronunciation of the vowel sounds. Whereas consonants are produced in different ways so that there are three factors involved in consonant pronunciation, namely: the state of the vocal cords, the touching or approach of various utterances, and the way the utensils touch or are close together (Carr, 2013). A combination of vowels is called a diphthong when it produces only one sound. For example, diphthong / au/ in the word kerbau; diphthong / ai/ on the word santai. Meanwhile, the combination of the vowel /au/ in the word bau is not a diphthong because it produces two sounds.

Several previous studies have been carried out on the phonological systems of regional dialects in some different regions. Terigan (2019) conducted a study on the development of phonological system made by young learners. The object of this research is to investigate and identify the phonological system made by children 3 years to 5 years old. This study uses descriptive qualitative analysis in order to figure out and identify the form of phonological and semantic system made by children at the age 3-5 years old. Observation and interview were used to collect the data. The research findings reveal that there are omissions in phonological system on children at the age 3-4 years, the consonant sounds of $/ \mathrm{k} /, / \mathrm{t} /, / \mathrm{r} /$, and $/ \mathrm{s} /$ and there is also sound replacement occurs in pronunciation made by the age 3-4 years like pronouncing sound /c/ with / s / and consonant sound / r/ with /1/. At the age of 5 years, the sound of consonant has been seen more clearly in the pronunciation of words. They have been able to recognize the sounds of consonant $/ \mathrm{k} /, / \mathrm{t} /, / \mathrm{r} /$, and $/ \mathrm{s} /$. In conclusion, the phonological system made by children 3 years to 5 years old can be seen from the difficulties of pronouncing sounds $/ \mathrm{t} /, / \mathrm{d} /, / \mathrm{r} /, / 1 /$, and the replacing of position of sounds/s/ with /c/ and also the latter /r/ with /1/.

Sari \& Syaputri (2019) conducted a study on the phonological system of Mentok dialect used in Pusuk, West Bangka Regency. This research was conducted to describe the phonological system in Mentok dialect used in Pusuk region, west Bangka, based on (1) vowels, (2) consonant system, (3) diphthong, (4) distributions of vowels, consonants, and diphthongs, and (5) 
phonemic principle. The method used in the study was qualitative method and utilized 248 basic vocabularies of Swadesh-based UnCen-SIL Wordlist. The data was collected with basic technique "conversation technique", followed by "noting and recording technique". The findings show that the phonological system in Mentok dialect used in Pusuk provides 9 vowels, 19 consonants, and 4 diphthongs. The distributions of vowel and consonant were incomplete and there was an allophone found in the study.

Siahaan et al. (2021) conducted a study on the management of phonotactic structure in the Toba Batak language. The management of vowel sequences and consonant sequences studied the sounds of language by imitating the speech of the speakers who used their language, studied the sounds of language guided by sound symbols, and how speech organs can produce sounds perfectly, and finally analyzed the sounds. The method used in this research is a qualitative method with interactive model that can reflect reality based on facts. Vowel sequences in this research consist of 44 pieces, that are: /ai-/, /-ai-/,/-ai/, /-ao-/, /-ao/, /au-/, /-au-/, /-au/, /ae-/, /-ae/,/-ae/, /ia-/, /-ia-/, /-ia/,/iu-/, /-iu-/, /-iu/, /io-/,/-io-/,/-io/, /ua-/, /-ua-/, /-ua/, /-ui-/, /-ue-/, /-ue/,/ea-/, /-ea-/, /- ea/,/-eu-/, /-eu/, /eo-/, /-eo/, /-oa-/, /-oa/, /-oi-/, /-oi/,/-io-/,/-ou/,/-uo/, /-aoa-/, /-uae/, /-aio-/, and /-aua-/. Consonant sequences in this research consist of 32 pieces, that are: a) consonant sequences started with /k/ sound, are: /-kl-/, $/-\mathrm{kb}-/, /-\mathrm{kp}-/$, and / -kt-/. b) consonant sequences started with /1/ sound, are: $/-1 \mathrm{t}-/ . /-1 \mathrm{~s}-/, /-\mathrm{lp}-/, /-\mathrm{lg}-/$, and $/-1 \mathrm{~b}-/$. c) consonant sequences started with /m/ sound, are: /-mb-/, /-mp-/, and /-ml-/. d) consonant sequences started with /n/ sound, are: /- nd-/, /-nj-/, /-nt-/, /-ns-/, /-ng-/, /-ngj-/, /-ngp-, /-ngt-/. e) consonant sequences started with /p/ sound, are: /-pr-/, /-ph-/, /-ps-/, and/-pg-/. f) consonant sequences started with /r/ sound, are: /-rg-/, /-rs-/, /-rj-/, /-rt-/, /-rh-/, and /-rn-/.g) consonant sequences started with /s/ sound, are: /-sr-/, /-sd-/, and /-st-/. h) consonant sequences started with / $\mathrm{t} /$ sound, are: /-tm-/ and /-ts-/

The present research describes the phonological system in the Toboali dialect and the sequence of phonemes that are possible in a language (Fata, 2014; Kridalaksana, 2008; Siahaan et al., 2021). The research problems are formulated to compare how people from different villages in the South Bangka regency pronounce words using the Toboali dialect and to describe the phonological system of the Toboali dialect used by the local people. The researchers managed to collect 203 words by using Swadesh's basic vocabulary.

\section{METHODS \\ Participants}


This study uses a qualitative descriptive method to identify and describe the phonological system of the Toboali dialect. The object of the study is the phonological process of the dialect spoken by the people who live in the South Bangka Regency. This research aims to describe the phonological system of the Toboali dialect qualitatively. Therefore, this study described the acquisition of field data, classified the data, and finally drew a conclusion qualitatively.

The selection of informants refers to the criteria proposed by Mahsun (2014) who states that the informants should be native speakers, do not have speech or hearing impairment, and can provide a corpus of data that is abundant, careful, and truly representative. The informants should be at least thirty (30) years old so that they have sufficient knowledge of language and culture to understand the instructions from the researchers.

10 informants who are native speakers of the Toboali dialect from five different regencies in South Bangka (Air Gegas District, Pongok Islands, Payung, Tukak Sadai, and Toboali Kota) were interviewed. The informants were chosen because they fulfilled the criteria as stated by Mahsun regarding the selection criteria of the informants. The criteria for becoming informants are possessed by them because they are very active in speaking the Toboali dialect in their daily lives. The percentage of speaking the Toboali dialect is $60 \%$ and the use of Indonesian language (only used when they work) is $40 \%$; The activeness of the Toboali dialect's language is also supported by the existence of the Toboali dialect speaking community in the area where they live in South Bangka.

\section{Instruments}

In collecting the data, the Swadesh list which consists of 250 vocabularies was utilized by asking the informants to pronounce the words. The researchers obtained the Toboali dialect words by gesturing or pointing to objects and images to the informants so they were able to pronounce the words and then the phonetic transcription could be written. Thus, the data obtained is accurate because the language obtained was not delivered in Indonesian but was purely pronounced in the Toboali dialect.

Several media were also used to collect the data. The recording device used was in the form of an Infinix X650C mobile phone to record the voice of the informant. Besides, the object is visualized with the Acer SW1-011 Laptop with a resolution of $1280 \times 800$ pixels while recording and typing through Microsoft Word 2013.

\section{Data Analysis Procedures}

The data was collected by conducting interviews, recording the conversations, and taking notes. The note-taking technique was used by 
researchers to record data that is related to the research problem. The data was carefully selected and arranged from the Swadesh list. Therefore, the phonetic transcriptions could be written.

Data that are difficult to understand by the researcher is then confirmed back to the informant by re-pronouncing the difficult word until the informant nods in agreement for checking the correct utterance. In addition, the researchers re-checked the sound of words using Sephonics software version 1.01 to synchronize the recording sound with phonetic sound on Sephonics. This software was downloaded from http:/ /ipa.typeit.org/ on August 21, 2020, at 21.48 WIB.

\section{FINDINGS}

\section{Phonological System}

This study analyzed the Phonological system of the Toboali dialect used by the people from 5 different Districts in the South Bangka Regency through lexical and phonetic perspectives. The interesting finding in this study is that there are some differences in the dialects from the 5 different regions, even though the Toboali dialects derive from the same family, the Bangka Malay language family. The differences in the phonological system or how the people from the 5 different areas in South Bangka pronounce words can be seen in Table 1.

Table 1. The Comparison of Toboali Dialects from 5 different sub-districts in South Bangka Regency

\begin{tabular}{|c|c|c|c|c|c|}
\hline $\begin{array}{c}\text { Toboali } \\
\text { Kota }\end{array}$ & Air Gegas & Payung & Lepar & Pongok & Meanings \\
\hline /demon/ & /dəmon/ & /dəmon/ & /dəmon/ & /dəmøn/ & Cold \\
\hline /jiat/ & /jaet/ & /jiət/ & /jiat/ & /jaet/ & Bad \\
\hline /loroh/ & /loroh/ & /luros/ & /loroh/ & /loroh/ & Straight \\
\hline /busu?/ & /buso?/ & /husv?/ & /buso?/ & /busu?/ & Rotten \\
\hline /kurooh/ & / kuroh/ & /kuros/ & /kuruoh/ & / kuroh/ & Thin \\
\hline /pənosh/ & /ponas/ & /pənoh/ & /pənooh/ & /ponoh/ & Full \\
\hline /tompool/ & /tompol/ & /tompol/ & /tompol/ & / tompol/ & Dull \\
\hline /aluh/ & /aloh/ & /alus/ & /aloh/ & /aluh/ & Smooth \\
\hline /basah/ & /basah/ & /bəsah/ & /basah/ & /basah/ & Wet \\
\hline
\end{tabular}

From the table, we can see that there is a sound change for vowels in Toboali dialects. The word demun (cold) is differently pronounced in 5 different villages because the speakers from the villages using a different form of the phoneme. Vowel [e] undergoes a change into allophone [ə] and vowel $[\mho]$ is varied into allophone [0]. The variant of sounds in different villages is unique. The word with suffix $-\mathrm{s}$ is pronounced [h] in Toboali Kota and Air 
Gegas area. However, the suffix $-\mathrm{s}$ is pronounced [s] in the Payung subdistrict.

\section{DISCUSSION}

Based on the findings, the discussion about the vowels, consonants, and Diphtongs found on the Toboali dialect can be made. There is a process of phonological change in every language and this is the reason why Toboali dialect undergoes the change in phonology (Diani \& Azwandi, 2021). The phonological change occurs when a speaker pronounces a word in a certain language by changing, adding, inserting, and a sound at the beginning, middle, and end of a word. The results of this study indicate that there are 7 vowels: [ə], [e], [o], [i], [o], [ซ], [a] and 19 consonants are found in the Toboali dialect: $[\mathrm{b}],[\mathrm{c}],[\mathrm{d}],[\mathrm{f}],[\mathrm{g}],[\mathrm{h}],[\mathrm{j}],[\mathrm{k}],[\mathrm{l}],[\mathrm{m}],[\mathrm{n}],[\mathrm{p}],[\mathrm{r}],[\mathrm{s}],[\mathrm{t}],[\mathrm{w}],[\mathrm{y}],[\mathrm{z}]$, and $[\eta]$. The discussion about the phonological system of the Toboali dialect can be seen below.

\section{Vowels}

All vowels are articulated with a stricture of open approximation and they are made by pushing air up from the lungs and allowing it to pass through the vocal tract without obstruction. Although usually produced with vibrating vocal cords, vowels may be pronounced without such vibration, resulting in a voiceless, or whispered, sound (Fata, 2014). From the viewpoint of articulatory phonetics, vowels are classified according to the position of the tongue and lips and, sometimes, according to whether or not the air is released through the nose.

The vowel sound can be determined based on the shape of the tongue and the position of the mouth. The shape of the tongue can be both vertical and horizontal. Two extreme-vowel heights may be distinguished: close (or high), where the tongue body is as near the hard or soft palate as it can be without causing audible friction, and open (low) where the jaw is lowered and the tongue body is as far as possible from the roof of the mouth (Todd et al., 2019). There are three kinds of vowels based on the area of the tongue, the front, the central, and the back vowels. The front vowels are [i], [e] and $[\varepsilon]$. The central vowel is [a]. The back vowels are [u] and [o]. Based on the data obtained, the vowels found in the Toboali dialect language can be seen in Table 2 and Table 3. 
Table 2. Vowels Description in the Toboali Dialect

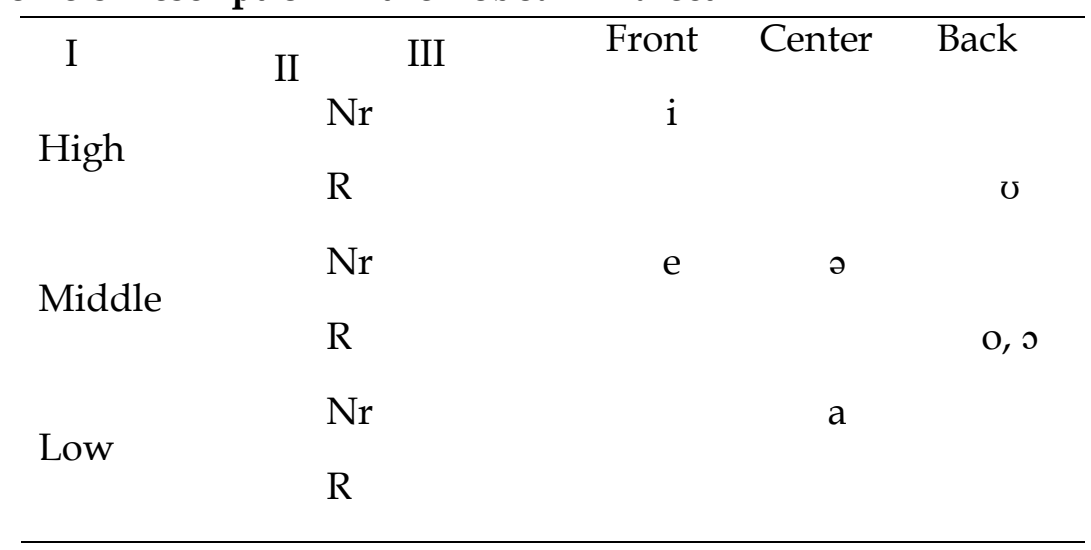

Table 3. Vowels in the Toboali Dialect

\begin{tabular}{cc}
\hline Vowels & Transcriptions \\
\hline$[ə]$ & /loma?/ \\
{$[\mathrm{e}]$} & $/$ tue/ \\
{$[\mathrm{i}]$} & $/$ itəm/ \\
{$[\mathrm{o}]$} & /hunot/ \\
{$[\mathrm{o}]$} & $/$ ponoh/ \\
{$[\mathrm{\sigma}]$} & $/$ lobei/ \\
{$[\mathrm{a}]$} & /agi?/ \\
\hline
\end{tabular}

From the tables above, we can see that the Toboali dialect has 7 vowel sounds. The following is the description of these Vowel sounds:

a. [0] sound

This is the Mid-Central Vowel which is often called the schwa sound but that refers to the symbol that is used it is nothing to do with the phonetics of the sound. In this case, the speaker's tongue is in the middle and the center of the mouth. All vowels are made through the mouth and are voiced so the speaker vibrates his/her vocal cords to make the sound. The example of [ə] sound in the Toboali dialect is /bərasu?/ - berburu (hunting).

b. [e] sound

This sound is the Close-Mid Front Unrounded Vowel. In this case, the speaker's tongue is high, but not at the top of the mouth, and at the front. Unrounded refers to the speaker's lips because they are stretched out and not rounded. For instance: /tue/- tua (old).

c. [i] sound 
The [i] sound is high and not rounded vowel. This vowel is formed when two lips are opened to the right and left sides of the face. For instance: /itəm/ - hitam (black).

d. [o] sound

It is the Close-Mid Back Rounded Vowel. This is formed when both lips are moved forward and a little bit rounded and the back of the tongue is raised. For instance:

/hunot/ - mulut (mouth)

/guso?/ - gosok (rub)

e. [o] sound

This sound is the Open-Mid Back Rounded Vowel. In this case, the speaker's tongue is low and at the back of the mouth. Rounded refers to the lips because they are pushed together like one is going to kiss somebody. For instance: / pənэh/ - penuh (full)

f. [ซ] sound

It is high and back rounded vowel. This vowel is formed by raising the tongue and both lips are moved forward and a little bit rounded. For instance: / lobei/- besar (big)

g. [a] sound

This sound is an open central unrounded vowel. The vowel is formed when the middle of the tongue spreads evenly and the mouth is widely opened. For instance: /agi?/ - lagi (again).

\section{Consonants}

Consonant is the sound of a language in which its formation the airflow that flows from lungs inhibited. A consonant is usually described, taking into account whether it is voiceless or voiced its place of articulation and its manner of articulation (Sari \& Syaputri, 2019). Voiced consonants will create vocal cord vibration meanwhile voiceless consonants will not create any vocal cord vibration.

The manner of articulation is the configuration and interaction of the articulators (speech organs such as the tongue, lips, and palate) when making a speech sound. Manner of articulation is specified according to the degree of stricture that is how closely the speech organs approach one another. Based on the data obtained, the consonants found in the Toboali dialect language can be seen in Tables 4 and 5 . 
Table 4. Consonants Description in the Toboali Dialect

Place of

Articulation

Bilabial Labio Alveolar Palatal Velar Glottal

Manner of

Articulation

\begin{tabular}{|c|c|c|c|c|}
\hline Plosives & $\begin{array}{l}/ \mathrm{p} / \\
/ \mathrm{b} /\end{array}$ & $\begin{array}{l}/ \mathrm{t} / \\
/ \mathrm{d} /\end{array}$ & / c / & $\begin{array}{l}/ \mathrm{k} / \\
/ \mathrm{g} /\end{array}$ \\
\hline Nasals & $/ \mathrm{m} /$ & $/ \mathrm{n} /$ & & /y/ \\
\hline Trills & & $/ \mathrm{r} /$ & & \\
\hline Fricatives & & /s/ /z/ & & \\
\hline Affricatives & $/ \mathrm{j} /$ & & & \\
\hline Lateral & & / $1 /$ & & \\
\hline Glide & $/ \mathrm{w} /$ & & /y/ & \\
\hline
\end{tabular}

Table 5. Consonants in the Toboali Dialect

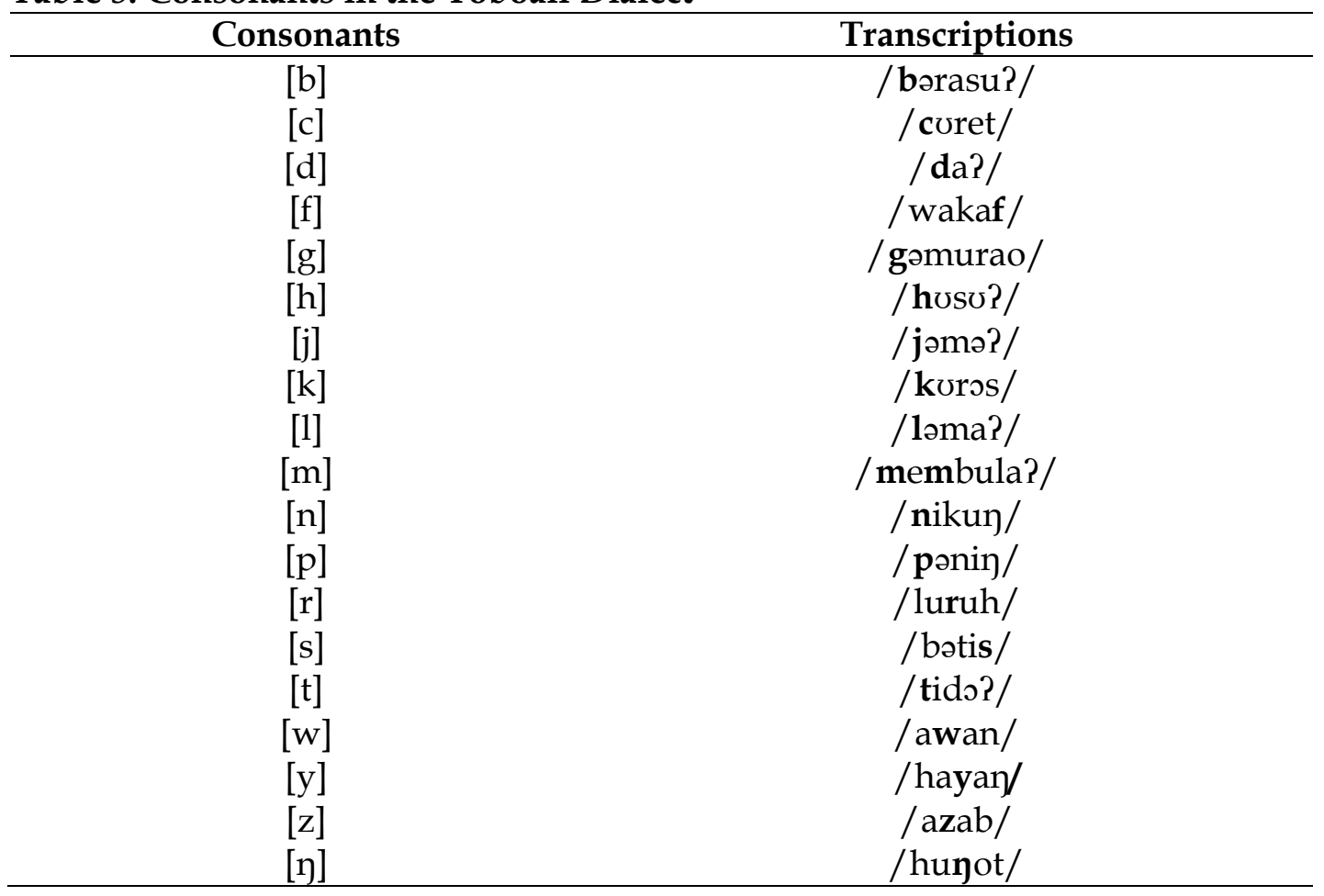

From the tables, it can be analyzed that some consonants in the Toboali dialect are found in some positions. The realization or the pronunciation of the 
consonant $/ \mathrm{t}$ / is considered common because it is found in all positions in the word, namely the initial, middle, and end positions in the word. For example: [tido?] - tidur (sleep), [botis] - betis (calf), [hunot] - mulut (mouth). The realization or the pronunciation of the consonant /c/ is only found at the initial position in the word. For example: [coret] - 'coret' (scribble).

\section{Diphthongs}

The diphthong is a vowel in which there is a noticeable sound change within the same syllable. However, the tongue position when pronounce the sound is up and down. Though they are single speech sounds, diphthongs are usually represented, in phonetic transcription of speech, utilizing a pair of characters indicating the initial and final configurations of the vocal tract (Carr, 2013; Cohn et al., 1992; Voeten, 2020). Many of the vowel sounds in most dialects of English are diphthongs: e.g., the vowels of "out" and "ice," represented as [au] and [ai], respectively. There are two types of a diphthong, those are closing and opening diphthong. In closing diphthongs, the second element is closer than the first e.g. [ai]; in opening diphthongs, the second element is more open e.g. [ia]. Closing diphthongs tend to be falling [ai], and opening diphthongs are generally rising [ia]. Based on the analysis, diphthongs in the Toboali dialect are mostly found in the middle and the end of a word can be seen in Table 4 .

Table 6. Diphthongs in the Toboali dialect

\begin{tabular}{|c|c|}
\hline Diphthongs & Transcriptions \\
\hline [च०] & / tompool / \\
\hline [ao] & /ponas/ \\
\hline [əu] & /kutəu/ \\
\hline [ai] & /petai/ \\
\hline [əI] & / pərapəi?/ \\
\hline [oi] & /amboi / \\
\hline [ia] & /nian/ \\
\hline [au] & /ijau/ \\
\hline [ua] & /tuan/ \\
\hline
\end{tabular}

The findings of this study reveal there is sound change (especially phonemic change) for phone [s] to [h] in the word sabun [habon] and sampo [hampo]. The variant of sounds in the word sama [hama] or [hame] in 5 different villages.

The variant of sounds in different villages is unique. The word with suffix $-\mathrm{s}$ is pronounced [h] in Toboali Kota and Air Gegas area. However, the suffix $-\mathrm{s}$ is pronounced [s] in Payung subdistrict. For example, the word lurus is pronounced differently in different districts. 
Toboali Kota Air Gegas Payung /loroh/ /loroh/ /loros/

The phonemic changes in Toboali dialects echo the Neogrammarian Hypothesis of sound change which postulated that sound change has no memory, ignores grammar, exceptionless, and inevitable (Kiparsky, 2016).

From the explanations above, it can be seen that the South Bangka Malay dialect in 5 different regions has similarities and differences in lexical terms. The difference found in this study is that there are striking differences in the dialects of the five regions, even though both dialects come from the same family, namely the Bangka Malay language family.

\section{CONCLUSION AND SUGGESTION}

The results of the study on the Toboali dialect of Bangka Malay language with a total of 250 vocabularies obtained from the informants can be elaborated as follows:

1. Malay Bangka language especially Toboali dialect which is spoken in 5 different districts in South Bangka has 7 vowels: [ə], [e], [o], [i], [o], $[v]$, and [a].

2. 19 consonants are found in the Toboali dialect spoken in 5 different districts in South Bangka: [b], [c], [d], [f], [g], [h], [j], [k], [1], [m], [n], [n], $[\mathrm{p}],[\mathrm{r}],[\mathrm{s}],[\mathrm{t}],[\mathrm{w}],[\mathrm{y}]$, and $[\mathrm{z}]$.

3. 9 diphthongs are found in the Toboali dialect spoken in 5 different districts in South Bangka: [vo], [aə], [əu], [ai], [əi], [əi], [ia], [au], and [ua].

4. The distribution of the Toboali dialect which is spoken in 5 different districts in South Bangka is not complete. The complete distribution is only [a], [e], [v], [o], [ə] and [i]. The other vowel-like [o] only occurs in the middle of the words.

5. The distribution of Malay Bangka language consonants especially Toboali dialect which is spoken in 5 different districts in South Bangka is not complete. The complete distribution is [b], [t], [m], [n], [n], [h], [r], [1] and the others, [d], [j], [c], [g], [k], [s], [n], and [?] are not complete.

6. Vowels, consonants, and diphthongs found in the Toboali dialect of the Bangka language are similar to vowels, consonants, and diphthongs found in other Malay language variants. The difference is clearly found in sound change (especially phonemic change) for phone [s] to [h] in the word sabun [habun] and sampo [hampo].

Considering the findings, the limitation of the present study focuses on analyzing the vowel, consonants, and diphthongs. Therefore, this study recommends the future research on the Toboali dialect can be conducted by using various theories and other approaches according to the expertise of the 
researchers to improve the comprehension of the phonological system in the Toboali dialect. Further researchers are suggested to study the phonological changes in another Bangka Malay dialect with more samples to reveal more comprehensive findings. This research is expected to be used as input for language teaching for educational institutions at the elementary and junior high school levels in Bangka Belitung Province.

\section{ACKNOWLEDGMENTS}

This research was funded by the Institute for Research and Community Service at Universitas Bangka Belitung (LPPM UBB) in 2020 with a research grant number 216/UN50.11/PP/2020. The authors thank the District and Sub-District heads from the following villages for permitting us to do the research at their areas: Air Gegas District, Lepar Island, Pongok Island, Payung, and Toboali Kota.

\section{REFERENCES}

Carr, P. (2013). English Phonetics and Phonology An Introduction. Blackwell Publishing Ltd, 1.

Cohn, A. C., Clark, J., \& Yallop, C. (1992). An Introduction to Phonetics and Phonology. Language, 68(1). https:/ / doi.org/10.2307/416373

Diani, I., \& Azwandi, A. (2021). Phonological Change Processes Of English And Indonesian. JOALL (Journal of Applied Linguistics and Literature), 6(1), 133-148. https:/ / doi.org/10.33369/JOALL.V6I1.13642

Fata, I. A. (2014). Is my stress right or wrong? Studying the production of stress by non-native speaking teachers of English. Studies in English Language and Education, 1(1). https:/ / doi.org/10.24815/siele.v1i1.1120

Gussenhoven, C. (2004). The phonology of tone and intonation. The Phonology of Tone and Intonation, 1-355. https:/ / doi.org/10.1017/CBO9780511616983

Hasan, A. (2007). Tata Bahasa Baku Bahasa Indonesia. Departemen Pendidikan Dan Kebudayaan Republik Indonesia, 29.

Kiparsky, P. (2016). Labov, sound change, and phonological theory. Journal of Sociolinguistics, 20(4). https:// doi.org/10.1111/josl.12196

Kridalaksana, H. (2008). Kamus linguistik edisi keempat. Jakarta: Gramedia Pustaka Utama.

Mahsun, M. (2014). Metode Penelitian Bahasa: Tahapan, Strategi, dan Tekniknya. In Jakarta: Raja Grafindo Persada.

Sari, D. P., \& Syaputri, K. D. (2019). A Study Of Phonological System Of Mentok Dialect Of Bangka Language In Pusuk District Of Kelapa West Bangka Region. Jurnal Ilmiah Bina Bahasa, 12(1). https:/ / doi.org/10.33557/binabahasa.v12i1.458

Siahaan, J., Sibarani, R., \& Barus, A. (2021). Phonotactics in Toba Batak 
Language: phonological Management. Academy of Entrepreneurship Journal, 27.

Terigan, K. E. (2019). The Development of Phonological System Made by the Children. Budapest International Research and Critics in Linguistics and Education (BirLE) Journal, 2(2). https:/ / doi.org/10.33258/ birle.v2i2.307

Todd, S., Pierrehumbert, J. B., \& Hay, J. (2019). Word frequency effects in sound change as a consequence of perceptual asymmetries: An exemplarbased model. Cognition, 185. https:/ / doi.org/10.1016/j.cognition.2019.01.004

Ulfa, M., Isda, I. D., \& Purwati, P. (2018). The shift of Acehnese language: A sociolinguistic study to preserve regional languages. Studies in English Language and Education, 5(2). https:/ / doi.org/10.24815/ siele.v5i2.8943

Voeten, C. C. (2020). Individual Differences in the Adoption of Sound Change. Language and Speech. https://doi.org/10.1177/0023830920959753 